\title{
QUIS CUSTODIET IPSOS CUSTODES?:ON BEING CRITICAL ABOUT CRITICAL PEDAGOGY IN PHYSICAL EDUCATION
}

\author{
QUIS CUSTODIET IPSOS CUSTODES?: SOBRE SER CRÍTICO NA PEDAGOGIA \\ CRÍTICA DA EDUCAÇÃO FÍSICA
}

\begin{abstract}
QUIS CUSTODIET IPSOS CUSTODES?:SOBRE SER CRIITICO EN LA PEDAGOGIA CRIITICA DE LA EDUCACIÓN FISICA
\end{abstract}

\section{David Kirk*}

\begin{abstract}
A challenge for critical pedagogy in physical education is how to take forward an agenda in circumstances of precarity while avoiding the many pitfalls, such as indoctrination, utopianism and self-conceit, that could diminish its effectiveness as well as its reputation. This paper considers the possibility of being critical about critical pedagogy while remaining passionate for the cause of social justice through education. To date, it has appeared to be sufficient for critical pedagogues in physical education to regulate themselves, but this has failed to produce any agreement on how critical pedagogy might respond, for example, to rising precarity. Five key points emerge from an analysis of Burbules' work on critical pedagogy. I consider how we might build self-awareness and self-critique into critical pedagogy in physical education, and by so doing address both the challenges raised by critiques of critical pedagogy and indeed the question itself of quis custodiet ipsos custodes?
\end{abstract}

Resumo: Um desafio para a pedagogia crítica da Educação Física tem sido o de como prosseguir adiante com sua agenda em circunstâncias de precariedade, ao mesmo tempo em que evita muitas armadilhas, como doutrinação, utopismo e arrogância, o que pode diminuir sua efetividade tanto quanto sua reputação. Este artigo considera a possibilidade de ser crítico em relação à própria pedagogia crítica, ao mesmo tempo em que permanece inflamado pela causa da justiça social através da Educação. Até hoje, ela parece ser suficiente para pedagogos críticos em Educação Física regularem a si mesmos, mas tem falhado em produzir qualquer concordância sobre como a pedagogia crítica pode responder, por exemplo, ao crescimento da precariedade. Cinco chaves de leitura emergem da análise de Burbules sobre ser crítico em Educação Física. Eu considero como nós deveríamos ser autoconscientes e autocríticos no âmbito da pedagogia crítica em Educação Física e, ao fazer isso, abordar seus desafios crescentes e, de fato, enfrentar a questão segundo a qual "quem vigia os próprios vigilantes"?

Resumen: Un continuo reto para la pedagogía crítica de la Educación Física ha sido como seguir adelante con su agenda en circunstancias de precariedad y, al mismo tiempo, evitar muchas trampas, como adoctrinamiento, utopismo y arrogancia, lo que puede disminuir su efectividad tanto como su reputación. Ese artículo considera la posibilidad de ser crítico en relación a la propia pedagogía crítica al mismo tiempo en que permanece motivado por la causa de la justicia social por medio de la Educación. Hasta hoy, ella parece ser suficiente para los pedagogos críticos regularse a sí mismos, pero ha fallado en producir cualquier concordancia sobre como la pedagogía crítica puede responder, por ejemplo, al crecimiento de la precariedad. Cinco claves de lectura emergen del análisis de Burbules sobre ser crítico en la Educación Física. Considero como nosotros deberíamos ser autoconscientes y autocríticos en el ámbito de la pedagogía crítica en Educación Física y, al hacer esto, abordar sus desafíos crecientes y, de hecho, enfrentar la cuestión sobre "¿quién vigila los propios vigilantes?".
*University of Strathclyde and University of Queensland. Glasgow, UK E-mail: david.kirk@strath.ac.uk

Received 05 June 2019

Accepted 11 September 2019 Published 15 November 2019

DOI: https://doi.org/10.22456/1982-8918.96244 (c) (1) \&) Licence 
If there is anything that we should have learned it is that no one approach works for all students, for all needs and interests, for all learning styles, for all ages, for all contexts. There is no approach certain to succeed, and there is no approach that will not have some detrimental effects, for some students, at the same time that it is benefitting others. Our choices, then, must also be about balancing, managing tensions, and working over time to revise and improve our efforts as we learn from our mistakes and failures. (BURBULES, 2016, p.4)

\section{INTRODUCTION}

Critical pedagogy has since its earliest appearance in the Anglophone scholarly literature in physical education been subject to criticism. An early critique by O'Sullivan, Siedentop and Locke (1992) argued that critical pedagogy inappropriately took the moral high ground, was over zealous in its arguments, and lacked evidence for many of its claims. Echoing another of O'Sullivan et al.'s criticisms, Gore (1998) claimed that many critical pedagogues failed to translate their critical vision into alternative practices. More recently, Fitzpatrick and Russell (2015) proposed that some critical pedagogues assume there is only one 'best' form of critical pedagogy, and go about imposing their approach on oppressed and marginalized youth in order to 'save' them. McMillan (2017), meanwhile, expressed his disapproval of critical pedagogy's negativity and failure to support its critique of physical education with evidence and in so doing judging teachers unfairly. On a similar note, Enright, Hill, Sandford and Gard (2014) bemoaned critical pedagogy's preoccupation with 'what is broken', and engaging in 'deficit scholarship'. Randall and Robinson (2016), editors of a recent book on social justice pedagogy, were critical of critical pedagogy's 'abstract and utopian transformation claims'. In his influential advocacy of a 'modest pedagogy', Tinning (2002) argued that the claims of critical pedagogues in physical education were "often overstated, utopian, and perhaps even wrong-headed" (TINNING, 2002, p.226).

While we could examine and debate the veracity and accuracy of each of these criticisms of critical pedagogy, its worth bearing in mind that many of these critics are themselves advocates for and practitioners of critical pedagogy. For this reason alone I think these criticisms need to be taken seriously. There are also some consistent points that run through these critiques. For instance, there is the notion that critical pedagogues have the 'right answers' to the challenge of social injustice; as such, critical pedagogues occupy the 'moral high ground', seeing further and more clearly than others. As a corollary, such a position creates division, an 'us' who agree with the critical pedagogues and a 'them' who do not. There is also the criticism that critical pedagogues' advocacies are utopian, abstract, overstated, and negative and that, moreover, they risk alienating teachers and pupils, the very people they seek to empower. Critical pedagogues' insistence that they are 'right' on the one hand risks indoctrination, while on the other it shows them instead to be 'wrong-headed' and thus raises the possibility that they may do more harm than good.

These criticisms, taken together, are of course a caricature of the actual work of critical pedagogues in physical education. Looking across the body of critical pedagogical scholarship, it is difficult to find examples of these criticisms in any obvious forms. Nevertheless, we must, in the process of being critical about critical pedagogy, take such possibilities seriously. Taking these criticisms seriously does not, however, mean that we must, following Tinning, seek more 'modest' positions. Indeed, I agree with Fitzpatrick's (2018) view that now is not the time to back away from pedagogical activism in and through physical education. As I have argued elsewhere 
(KIRK, 2020), the increasing prevalence of precarity in the Global North is putting more and more young school age people at risk not just of poverty but also of the threats to health and wellbeing that living with uncertainty and instability bring. As such, critical pedagogy is more relevant and important than ever as curriculum policy in many countries has shifted from a conceptualization of physical-as-sport-techniques to physical education-as-health promotion. With an explicit policy remit for the health and wellbeing of children and young people, many of whom are living in precarity right now, not at some distant and hypothetical point in the future, physical educators need new forms of pedagogy to support and empower these young people.

The challenge is how to take forward a critical pedagogy agenda in circumstances of precarity while avoiding the many pitfalls that could diminish its effectiveness as well as its reputation. Is it possible to be critical about critical pedagogy while remaining passionate for the cause of social justice through education? Is it sufficient for critical pedagogues in physical education to regulate themselves, as appears to be the case based on the critiques just mentioned? While such critique is important, the only broad consensus we appear to have reached within the Anglophone critical pedagogy community is Tinning's 'modest' pedagogy, which is widely, approvingly and uncritically cited by many (KIRK, 2020). I will argue however that this proposal may be insufficient in the face of rising precarity, and that we need forms of critical pedagogy that can provide teachers with the necessary educational response to precarity. Nevertheless, we must in proposing more suitable alternatives be careful of the challenges already identified. We need critical pedagogies of physical education that have built in, so to speak, forms of self-awareness and self-critique that avoid utopianism, indoctrination, and self-conceit. For, otherwise, who, indeed, will watch the watchers?

\section{BURBULES ON BEING CRITICAL ABOUT BEING CRITICAL}

In an extended response to a critique of his work by Sibbett (2016) in the journal Education \& Democracy, Burbules (2016) reflected on the process of being critical about being critical. In so doing, he argues for the central role of communication in all forms of education for democratic citizenship and activist pedagogy. He writes

Actual processes of communication are the place where second-order principles of social and political commitment get worked out in practice, and our abilities to make these processes of communication work are essential to the success of coordinated action and understanding directed toward progressive change. (BURBULES, 2016, p.2)

Burbules illustrates the importance of making communication work by highlighting the inadequacy of the liberal tradition and the values of pluralism, tolerance and reasonable deliberation, values that readily find a home in traditional educational contexts. These values usually work fine for those who are able to participate in the conversation. In conditions of gross inequality, however, these values do little to aid those who are excluded and have no voice. Consensus thus may be built as much on the exclusions from a communicative process as the deliberations and debates of those who are included. What is required in conditions of inequality then is "[...] a critical orientation that can recognize, question, and give voice to those exclusions" (BURBULES, 2016, p.2).

Sibbett's (2016) response to these failings of liberal democracy is to propose three ideas for democratic and inclusive citizenship. The first is a concept of a 'decentred unity' borrowed from Apple. Apple explains that decentred unities are 
Spaces that are crucial for educational and larger social transformations that enable progressive movements to find common ground and where joint struggles can be engaged in ways that do not subsume each group under the leadership of only one understanding of how exploitation and domination operate in daily life. (APPLE, 2013, p.13)

Decentred unities are then 'alliances across differences' that enable strategic cooperation among groups without these groups losing their identities to others. A second idea emphasizes the importance of local action through participatory and justice-oriented citizenship. Sibbett recognises actual engagement in governance and of how domination works out in specific and concrete aspects of everyday life are crucial to democratic citizenship. Her third idea is wholeheartedness, which acknowledges the importance of both reason and emotion in all political action, and the co-habitation of tensions among sentiments such as hope and despair.

Building on these three ideas of Sibbett's, Burbules proposes that there are two forms of communication embedded in activist pedagogy, one that is designed to achieve particular outcomes through education, and another that aims towards understanding and may result in unpredictable and unanticipated conclusions. Specifically, activist pedagogy and its constitutive activities for Burbules,

Continually raise the question of whether the goal is to bring about a specific state of affairs that the pedagogue has in mind, and which students are intended to believe in and work toward, or whether it is to enable and empower students to make choices, set goals, and pursue actions that may yield a range of possible outcomes - some of which may be quite different to what the pedagogue has in mind. (BURBULES, 2016, p.2)

The first position, which Burbules argues is a form of critical pedagogy that is the legacy of its Marxist roots, requires a pedagogue who presumes to already know what is good for others, and thus limits itself to the question of transformation from condition $A$ to condition $B$. The second position, in contrast, has no concept of an endpoint such as condition $B$, but is concerned instead to empower young people to determine their own futures, individually and collectively. For Sibbett, preference for the second position was crucial in order to avoid the risk of indoctrination which, for Burbules, is the key pedagogical issue in educational contexts. It is also a means of avoiding accusations of utopianism. In terms of communication, the choice is between a form that is strategic, with a specific end in view, and a form that is more 'open-ended'.

Burbules argues that the notion of a decentred unity is a good example of the latter, in the sense that such a coalition of forces cannot determine outcomes of their alliance in advance. Moreover, in discursive terms they create a 'third space' that does not eliminate conflicts and disagreements among them, but creates a framework for approaching these conflicts with different and productive perspectives that may make the reasons for disagreements better articulated and understood. Indeed, in Mouffe's (2018) terms, such spaces are essential to facilitate agonistic discourse, which permits the nature of domination to be brought into clearer view and as such is a key feature of what she calls radicalized democracy.

In terms of Sibbett's second idea of participatory and justice-oriented citizenship, Burbules draws a distinction between deliberative and activist speech. A deliberative form of communication involves speaking with, while an activist form is speaking to, at or against. He provides a simple example. Deliberative speech is essential once you have a 'seat at the table', once you have a voice in the conversation. However, in order to gain that seat, to be included in 
the conversation, activist speech is important, since it challenges why you are excluded and on what bases others are included. Both forms of communication are important, argues Burbules, but each follows different rules and requires particular capabilities.

Warming to his argument about the need to recognize these different forms of communication in participatory citizenship, Burbules writes

\begin{abstract}
Another legacy of the Marxist tradition is a dichotomous view of conflict: Group $A$ is always right, and group $B$ is always to blame; all conflict is the result of $X$, and if you can just transform or overthrow $X$, everything will be better. Many left critical positions still derive from this mode of thinking, and their conception of transformation is accordingly thin. The sources of human conflict are multiple and cannot to traced to just one source (...) what we need, I would suggest broadly, is an ongoing, iterative process of critique, reform, and self-questioning. There is no utopian end state. (BURBULES, 2016, p.3)
\end{abstract}

According to Burbules, a focus on communicative form is helpful when considering participatory and justice-oriented citizenship since it permits us to see the different functions of deliberative and activist speech. Both are necessary, and it is essential politically and educationally that their different purposes are understood and practiced appropriately.

Turning to Sibbett's third idea of wholeheartedness, Burbules agrees with her that emotion and feeling are inseparable from political commitments and their articulation in political language. But, while acknowledging the importance of affect, he cautions that 'visceral outrage' may get in the way of seeing possibilities for alternatives to injustice and domination. Indeed, he agrees with Sibbett that it is education's role to assist students to understand where strong emotion, left to itself, can lead to indoctrination, to good intentions gone wrong, and to the creation of absolutisms that are as oppressive as those they replace. Thus, he argues, deliberation and the pursuit of reasonableness and compromise are not the opposite of activist speech, but its desired objectives. Returning to his simple example, once you have a seat at the table, the language of demands can only produce limited if any returns. Understanding this point is crucial to education for democratic citizenship. Again he cautions,

\begin{abstract}
An activist pedagogy that is not clear about its educational goals may become indoctrinatory. An activist pedagogy that focuses only on the capacity for critique and not on the capacities and dispositions for positive, transformative action may leave students angry but futile. An activist pedagogy that neglects the institutional and other arenas in which citizenship actually happens will not provide students with the skills and understandings to be effective agents of change. (BURBULES, 2016, p. 4)
\end{abstract}

As such, Burbules argues that the search for a single solution that will transform condition A into condition $B$, now and forevermore, is folly. It is nevertheless a continuing tendency within critical pedagogy, and must be resisted because it is illusory. It is also the source of many of the criticisms directed at reformists in physical education and what Lawson (2018), calls the 'standardization impulse'.

\title{
3 FIVE POINTS TO CONSIDER ABOUT BUILDING AWARENESS AND SELF-CRITIQUE
}

Burbules' reflections on being critical about being critical yield five key points for us to consider in terms of how we might build self-awareness and self-critique into critical pedagogy in physical education, and by so doing address both the challenges raised by critiques of critical pedagogy and indeed the question itself of quis custodiet ipsos custodes? 
The first point derives from Burbules' distinction between two forms of communication within participatory citizenship and activist pedagogy, one that is strategic and ends-focused, and another that is for understanding and is open-ended. Behind the first form is the pedagogue who has a vision for a socially just society. As such, this pedagogue knows what is best for children and youth and is concerned primarily with how to lead a transformation from where we are now to where we need to be. The danger of this position, no matter how visionary the pedagogue, is according to Sibbett and Burbules, indoctrination, not education. In contrast, their second form of communication has no end in view, since it is instead an ongoing, reflective, iterative process. In this context, the focus is on empowering young people to think for themselves, to make choices and set their own goals, to be able to adapt to changing circumstances.

Biesta $(1998$, p.500) supports this second form of communication in his view of the impossibility of critical pedagogy, in the sense that the future "cannot be foreseen and calculated as a possibility". It is not possible then for critical pedagogues to know the future. Nor can they know specifically what is good for all young people in all circumstances and how young people will respond to their teaching. Moreover, as Burbules notes, there can be no one approach. While a critical pedagogue may have particular preferences and desires for socially just forms of physical education, the imposition of these preferences on young people is indeed tantamount to indoctrination.

An open-ended form of communication within activist pedagogy would appear to avoid the pitfall of indoctrination and the risk of utopianism, and accept the impossibility of critical pedagogy in Beista's sense. This does not mean that we must adopt a relativist position instead, that anything goes. It will be important for critical pedagogues to provide broad frames of reference for pedagogy, as their contribution to the intellectual labour they share with teachers, young people, and other stakeholders. For example, all (presumably) would want to argue for the educational importance of physical education in schools. In so doing, we would want to hear persuasive arguments from critical pedagogues about physical education's educational potential to benefit young people, and advice on the kinds of programmes that might provide such benefits. Any such recommendations and prescriptions would, however, need to be framed as contingent, as in need of adaptation to suit the particularities of local contexts, a point we come to below. Open-ended does not need to imply that critical pedagogues have no vision for improving physical education, but it does firmly assert that this is only one of several possible perspectives.

A second key point is that since there is no one best approach we must talk about critical pedagogies of physical education, in the plural. Indeed, if critical pedagogues are to frame broad principles and possibilities for critical forms of physical education, and if physical education is to be practiced in diverse circumstances, then we should be considering a multiplicity of approaches. It will be important again that we do not assume a relativist position. What is to count as physical education must be recognized as such, without at the same time proposing narrow prescriptions and definitions. A definition of critical pedagogies of physical education will be important within the institutional context of the school, where curriculum time and pedagogical spaces are jealously guarded.

A third point draws on the notion of a decentred unity analogously to consider how critical pedagogies of physical education can be inclusive, with the possibility that they can provide educational benefits to diverse pupils in schools. How can all voices be recognized and 
included in the conversation of physical education? One of the frequent criticisms of school physical education programmes in many educational systems of countries of the Global North is that they are informed by what Fitzpatrick and McGlashin (2018) call 'straight pedagogies'. For these authors, straight pedagogy is dominant in physical education programmes that seek to shape young people's habitus to suit their requirement rather than "[...] seeing the field needing to embrace and recognize a more diverse range of habitus" (FITZPATRICK; MCGLASHAN, 2018, p.113). One way to do this may be to draw on the activist work of scholars such as Oliver (OLIVER; KIRK, 2015) to engage young people in co-constructing their physical education programmes with their teachers and peers. Part of the challenge of co-constructing the curriculum is to create the conditions in which teachers and pupils can engage with each other respectfully and safely and where difference can be celebrated.

A fourth point draws on Sibbett's notion of participatory and justice-oriented citizenship, which emphasizes the primacy of the local. Participation implies action in specific contexts, while social justice takes specific forms in specific locales. Traditionally in physical education, the 'standardization impulse' has prompted physical educators to play down the local and to encourage teachers and pupils to accept top-down prescriptions for practice. More recently and increasingly curriculum policy makers have recognized the folly of this approach, where they have worked with teachers (though less often with pupils) to create what the OECD (2015) call 'broad and bold' designs such as guidelines and frameworks. These designs provide structure and advice but also the 'spaces for manoeuvre' schools require to shape curricula to meet local needs and interests (PRIESTLEY et al., 2012). Kirk and Macdonald (2001) provide empirical evidence of school-based curriculum development in Australia to illustrate the importance of the 'local context of implementation' of curriculum innovation and change. They also argue that transformation of innovative ideas that originate outside of the school are inevitable and cite the 'iron law of curriculum innovation' that 'the innovative idea is always and inevitably transformed in the process of implementation.

Once again, recognizing the primacy of the local does not mean that contributions to the development of critical pedagogies of physical education external to the local context are inappropriate. We can again take the notion of a decentred unity analogously to consider how the tensions surrounding locality can be managed and the process be inclusive of all stakeholder voices, without any single agenda taking precedence. Scholars of critical pedagogy must share the intellectual labour of constructing appropriate forms of physical education with teachers, pupils and other stakeholders. One way this might happen, in addition to the provision of 'broad and bold' curriculum designs by the state, is through the use of pedagogical models (KIRK, 2013). Pedagogical models seek to manage the tension between external and internal (to the school) contributions to pedagogical development by providing a design specification, with a structure of main idea, critical elements and learning aspirations, to guide the co-construction of school-based programmes. Examples of the testing of these design specifications for practice can be found for example in Kirk et al., (2018), and Luguetti et al., (2017).

A fifth key point draws on Sibbett's notion of wholeheartedness and identification of the importance of emotion and reason in educational and political communication. In his 'modest pedagogy' paper, Tinning (2002) makes much of the post-structuralist critique of Enlightenment faith in the power of reflection to produce 'the truth', and sees this correctly as an argument against the tendency in critical pedagogy towards utopianism. Burbules (2016) makes a related 
criticism of Habermas's theory of communication, which he claims is conceived in 'almost purely cognitive terms'. Both authors make important corrective criticisms. In circumstances of precarity, where uncertain and insecure work leads to an inability to imagine a future and to being 'trapped in the present' (STANDING, 2016, p. 21-22), one casualty is what Antonovsky (1979) calls 'Sense of Coherence' (SoC), an ability to see life as comprehensible, manageable and meaningful. Antonovsky's salutogenic theory of health promotion argues that people who manage to stay healthy tend to have a stronger SoC than those who do not. All of this suggest that emotion plays a much more important part in human society than is often credited in educational and political discourses.

At the same time, in highlighting the place of emotion in educational and political communication, neither criticism rules out the importance of reflection and conscientization (FREIRE, 2005). Early in her activist work with girls, Oliver argued for the importance of critical reflection alongside the recognition of affect.

Until girls can name what oppresses them and prevents them becoming healthy women they remain powerless. If girls can learn to identify the forms of their oppression and name preferred possibilities, they can begin to disrupt the forces of their own oppression. (OLIVER, 1999, p.243)

Oliver here provides a good illustration of Burbules' (2016) recommendation for the formulation of positive alternatives. We have already noted his argument that 'visceral outrage' may be the starting point of critique but may eventually get in the way of conceiving alternatives to inequality. Deliberation and reasonableness indeed, for Burbules, are an important outcome of activist speech. Sibbett's concept of wholeheartedness thus provides a valuable emphasis on the whole person within critical pedagogy and a helpful way of holding both reflection and affect in tension within the critical pedagogy frame.

\section{CRITICAL PEDAGOGIES OF AFFECT IN PHYSICAL EDUCATION}

I am proposing that these five key points could form, if not a consensus, then the basis of at least a broad agreement on critical pedagogy in physical education that would offer a positive response to the criticisms physical education and other scholars have made. I am suggesting that adoption and incorporation of each of these points could provide some inbuilt self-awareness and self-criticism of critical pedagogies in practice, and in so doing temper the risks of indoctrination, self-conceit, negativity, and utopianism.

Adoption and incorporation of these five key points may also help to identify with greater clarity the nature of critical pedagogies in physical education. Another criticism of critical pedagogy by physical education scholars is a proliferation of terminology. Philpot, Gerdin and Smith (2019), for example, argue this is a potential source of confusion and misunderstanding. To paraphrase Shelley and McCuaig (2018), within physical education alone there is 'critical pedagogy, critical inquiry, critical education, critically oriented, inquiry-oriented, socially critical research/work/discourse, critical thinking, reflective teaching, and transformative pedagogies'. Not only this, there is the additional issue that some forms of critical pedagogy do not use any of this terminology thus adding to the potential for confusion and lack of clarity.

As one means of approaching this issue of clarity in my book Precarity, critical pedagogy and physical education, I offered a distinction between socially critical scholarship on the one 
hand and critical pedagogy on the other (KIRK, 2020). Socially critical scholarship, I suggested, is concerned primarily with analysing and troubling the normative order of physical education. Using a variety of theories and methods, it seeks to grasp and render comprehensible the complexity of life in physical education classes and teacher education programmes. It also seeks to uncover vested interests, unfair, and inequitable practices. We can take an example from the literature on girls and physical education. The works of Vertinsky (1992), Flintoff and Scraton (2001), Garrett (2004), and Azzarito (2009) provide socially critical analyses of gender identity, inequity and their intersections with race and class. This socially critical scholarship may hold implications and indeed make explicit recommendations for pedagogy, but these authors are not primarily concerned with educational action.

Critical pedagogy more specifically is concerned with the organization and alignment of curriculum, teaching, learning and assessment in ways that render physical education inclusive, fair, and equitable as an embodied experience for young people (STANDAL, 2015). Through this experience, critical pedagogy seeks to empower young people (OLIVER; KIRK, 2015). The activist work of Oliver et al., (2009), Enright and O'Sullivan (2010) and Fisette and Walton (2014) provide examples of critical pedagogy on this same topic of girls and physical education. Some activist projects these authors have undertaken draw on socially critical scholarship to frame and inform this educational action and also recruit critical inquiry to assist in the pedagogical process.

At root, both socially critical scholarship and critical pedagogy share a concern for social justice (MCCUAIG; ATKIN; MACDONALD, 2019; MACDONALD, 2004). This shared commitment to social justice means there are areas of overlap and complementarity. In the Precarity book, I argue, indeed, that many of the criticisms of 'critical pedagogy', on closer examination, are in fact criticisms of socially critical scholarship (KIRK, 2020). I think this point is important to note because the criticisms, though perfectly sound, have been misdirected. Thus, for example, Gore's concern cited earlier that many critical pedagogues fail to translate their critical visions into practice is, I suspect, more a criticism of socially critical scholarship than critical pedagogy as I have defined them. Gore's criticism is less likely to be about critical pedagogy since it is already a form of educational practice.

In the book, I identify three exemplary critical pedagogies of physical education that I think are well suited to working with young people experiencing precarity. These are the Teaching Personal and Social Responsibility approach developed by Hellison (1995), various forms of Sport Education such as Sport for Peace (ENNIS et al., 1999), a Cultural Studies approach (O'SULLIVAN; KINCHIN, 2015) and Empowering Sport (HASTIE; BUCHANAN, 2000), and activist approaches to working with girls (OLIVER et al., 2009) and boys (LUGUETTI et al., 2017; WALSETH; ENGEBRETSEN; ELVEBAKK, 2018). Significantly, none of these approaches uses critical pedagogy as a descriptor. They each nevertheless match my definition of critical pedagogy as the organization and alignment of curriculum, teaching, learning and assessment in ways that render physical education inclusive, fair, and equitable as an embodied experience that seek to empower young people. While the young people each of these scholar-teachers (HELLISON; OLIVER; HASTIE) work with may not be formally recognized as living in precarity, they share many of the same experiences, such as multiple-deprivation, and many of the same characteristics, such as alienation, anger, anxiety and anomie.

I describe all three approaches as critical pedagogies of affectbecause they work explicitly though not exclusively to achieve learning in the affective domain, in terms of, for example, 
resilience, perseverance, confidence, self-belief, interest and fun. In circumstances of precarity, where Sense of Coherence is undermined and damaged, the focus on affect can be thought of as the leading edge rather than the whole of these approaches. Cognitive, social and physical learning remain important. These critical pedagogies, with affect as their leading edge, have the potential to be empowering because through them young people have the potential for youth to experience embodied self-knowledge, self-awareness, and awareness of the relationships of embodied self to others (HELLISON, 1978). They may also then become disposed to question the taken for granted, to care about injustice and unfairness, for themselves and others, to be bothered to take positive action on their own and others' behalves. This said, whatever aspirations the creators of these approaches may hold for their work with young people, they cannot of course know what effects they will have on them individually and collectively.

Tested against the five key points outlined earlier, however, each of these critical pedagogies of affect stands up. Each seek to work with young people to support them to develop their own capacities. None has a utopian end in sight. Instead, each approach is iterative and contingent, with the teacher-scholars seeking to learn from their failures and successes. Some such as Oliver's activist approach explicitly involve co-construction of school physical education programmes, starting not from what the teacher thinks is necessary, but from where the young people are individually and collectively. Each recognizes the need for the localization and contextualization of physical education to better meet young people's needs and interests. All require collaboration between key stakeholders such as students, teachers and researchers. And while the language of wholeheartedness is not used in these specific examples, in each approach young people are viewed holistically, not as categories of persons (such as 'underserved' or 'disadvantaged' with the assumptions that sometimes come with such categories) but as human beings, exemplified in Hellison's descriptor of his work as humanistic physical education.

\section{CONCLUSION}

This paper has been an attempt to be critical about being critical in physical education, and has sought to offer something of a response to the question quis custodiet ipsos custodes, who watches the watchers?. I believe criticism of critical pedagogy and of socially critical scholarship is important. What I have tried to offer here is a basis for such critique. As I have argued here and elsewhere (KIRK, 2020) some of the criticisms of critical pedagogy have been misdirected, in part because we have lacked clarity about the nature of critical pedagogy in physical education. TPSR, various adaptations of Sport Education, and activist work are offered here as just three examples of critical pedagogies that have a particular focus on learning in the affective domain, which I believe to be crucial in the face of rising precarity. These three examples by and large fit the definition I offered for critical pedagogies in physical education. A challenge for our field is to develop more of these pedagogies, though need should drive this process.

My direct response to the question of who should watch the watchers? is that no single person or body should. We must instead watch ourselves, and in order to do this we need to have points of reference for debate and critique. In further developing these five points we should proceed as Burbules (2016) advocates on the basis of deliberative communication, seeking 
positive alternatives to current problems while recognizing and acknowledging disagreements and points of conflict. My view is that we have lacked a basis for such deliberation about critical pedagogies in physical education. As such, we have also lacked collectively direction and purpose. While consensus may well be illusory, we nevertheless need to have more fruitful debates about how we respond, pedagogically and politically, to social turbulence generally and to the rise of precarity and its mal effects on young people's health and wellbeing in particular. There is no watcher other than ourselves, as a complex community of scholar-practitioners of physical education, to do this.

\section{REFERENCES}

ANTONOVSKY, Aaron. Health, Stress and Coping. San Francisco: Jossey-Bass, 1979.

APPLE, Michael. Can Education Change Society? New York: Routledge, 2013.

AZZARITO, Laura. The panopticon of physical education: Pretty, active, and ideally White. Physical Education \& Sport Pedagogy, v. 14, n. 1, p. 19-39, 2009.

BIESTA, Gert. Say you want a revolution...Suggestions for the impossible future of critical pedagogy. Educational Theory, v. 49, n. 4, p. 499-510, 1998.

BURBULES, Nicholas. Being critical about being critical. Democracy \& Education, v. 24, n. 2, p. 1-5, 2016.

ENNIS, Catherine et al. Creating a sense of family in urban schools using the "Sport for Peace" curriculum. Research Quarterly for Exercise and Sport, v. 70, n. 3, p. 273-285, 1999.

ENRIGHT, Eimear. Looking beyond what's broken: towards an appreciative research agenda for physical education and sport pedagogy. Sport, Education and Society, v. 19, n. 7, p. 912-926, 2014.

ENRIGHT, Eimear; O'SULLIVAN, Mary. 'Can I do it in my pyjamas?' Negotiating a physical education curriculum with teenage girls. European Physical Education Review, v. 16, n. 3, p. 203-222, 2010.

FISETTE, Jennifer; WALTON, Teres. 'If You Really Knew Me' ... I am empowered through action. Sport, Education and Society, v. 19, n. 2, p. 131-152, 2014.

FITZPATRICK, Katie. What happened to critical pedagogy in physical education? An analysis of key critical work in the field. European Physical Education Review, v. 25, n. 4, p. 1128-1145.

FITZPATRICK, Katie; MCGLASHAN, H. Rethinking straight pedagogy: gender, sexuality and physical education. In: RANDALL, Lynn; ROBINSON, Daniel. Social Justice in Physical Education: critical reflections and pedagogy for change. Toronto: Canadian Scholars, 2017. p. 102-121.

FITZPATRICK, Katie; RUSSELL, Dan. On being critical in health and physical education, Physical Education and Sport Pedagogy, v. 20, n. 2, p. 159-173, 2015. 
FLINTOFF, Anne; SCRATON, Sheila. Stepping into leisure? Young women's perceptions of active lifestyles and their experiences of school physical education. Sport, Education and Society, v. 6, n. 1, p. 5-21, 2001.

FREIRE, Paulo. Teachers as Cultural Workers: letters to those who dare teach. Boulder, Colo: Westview , 2005.

GARRETT, Robyne. Negotiating a physical identity: Girls, bodies and physical education. Sport, Education and Society, v. 9, n. 2, p. 223-237, 2004.

GORE, Jennifer. On the limits to empowerment through critical and feminist pedagogies. In: CARLSON, Dennis; APPLE, Michael. Power/Knowledge/ Pedagogy. Colorado: Westview, 199). p. 271-288.

HASTIE, Peter; BUCHANAN, Alice. Teaching responsibility through sport education: Prospects of a coalition. Research Quarterly for Exercise and Sport, v. 71, n. 1, p. 25-35, 2000.

HELLISON, Don. Teaching Responsibility Through Physical Activity, Champaign: Human Kinetics, 1995.

HELLISON, Don. Beyond Bats and Balls: Alienated (and other) youth in the gym. Washington, DC: AAHPERD, 1978.

KIRK, David. Precarity, critical pedagogy and physical education. London: Routledge, 2020.

KIRK, David. Educational value and models-based practice in physical education. Educational Philosophy and Theory, v. 45, n. 9, p. 973-986, 2013.

KIRK, David et al. Balancing prescription with teacher and pupil agency: Spaces for manoeuvre within a pedagogical model for working with adolescent girls. The Curriculum Journal, v. 29, n. 2, p. 219-237, 2018.

KIRK, David; MACDONALD, Doune. Teacher voice and ownership of curriculum change. Journal of Curriculum Studies, v. 33, n. 5, p. 551-567, 2001.

LAWSON, Hal. Physical education in the industrial age school: An institutional perspective, In: LAWSON, Hal. Redesigning Physical Education: an equity agenda in which every child matters. London: Routledge, 2018. p. 23-40.

LUGUETTI, Carla et al. Exploring an activist approach to working with boys from socially vulnerable backgrounds in a sport context. Sport, Education and Society, v. 17, n. 4, p. 493-510, 2017.

MACDONALD, Doune. Critical pedagogy: what does it look like and why does it matter? In: LAKER, Anthony. The Sociology of Sport and Physical Education: an Introductory Reader. London: Routledge, 2004. p. 167-189.

MCCUAIG, Louise; ATKIN, Janice; MACDONALD, Doune. In pursuit of critically oriented physical education: Curriculum contests and troublesome knowledge. In: PRINGLE, Richard; LARSSON, Hakkan; GERDIN, Göran. Critical Research in sport, health and Physical Education. London: Routledge, 2019. p. 119-133.

MCMILLAN, Paul. Understanding physical education teachers' day-to-day practice: Challenging the 'unfair' picture. In: THORBUNR, Malcolm. Transformative learning and teaching in Physical Education. London: Routledge, 2017. p. 159-175. 
MOUFFE, Chantal. For a Left populism. London: Verso, 2018.

OLIVER, Kimberly. Adolescent girls' body-narratives: Learning to desire and create a "Fashionable" image. Teachers College Record, v. 101, n. 2, p. 220-246, 1999.

OLIVER, Kimberly; KIRK, David. Girls, Gender and Physical Education: an activist approach. London: Routledge, 2015.

OLIVER, Kimberly; HAMZEH, Manal; MCCAUGHTRY, Nate. Girly girls can play games / Las niñas pueden jugar tambien: Co-creating a curriculum of possibilities with fifth-grade girls. Journal of Teaching in Physical Education, v. 28, p. 90-110, 2009.

OECD . Organization for Economic Co-operation and Development. Improving schools in Scotland: an OECD perspective. 2015. Disponível em: http://www.oecd.org/education/school/ Improving-Schools-in-Scotland-An-OECD-Perspective.pdf Acesso em: 20 jan. 2017.

O'SULLIVAN, Mary; KINCHIN, Gary. Cultural studies curriculum in physical activity and sport. In: LUND, Jacalyn; TANNEHILL, Deborah. Standards-Based Physical Education Curriculum Development. $3^{\text {rd }}$ ed. Burlington: Jones \& Bartlett, 2015. p. 333-365.

O'SULLIVAN, Mary; SIEDENTOP, Daryl; LOCKE, Lawrence. Toward collegiality: Competing viewpoints among teacher educators, Quest, v. 44, p. 266-280, 1992.

PHILPOT, Rod; GERDIN, Göran; Smith, Wayne. Socially critical PE: The influence of critical research on the social justice agenda in PETE and PE practice. In: PRINGLE, Richard; LARSSON, Hakkan; GERDIN, Göran. Critical Research in sport, health and Physical Education. London: Routledge, 2019. p. 134-146.

PRIESTLEY, Mark et al. Teacher agency in curriculum-making: Agents of change and spaces for manoeuvre. Curriculum Inquiry, v. 42, n. 2, p. 191-214, 2012.

RANDALL, Lynn; Robinson, Daniel. Social Justice in Physical Education: Critical reflections and pedagogy for change. Toronto: Canadian Scholars, 2017.

SHELLEY, Karen; MCCUAIG, Louise. Close encounters with critical pedagogy in socio-critically informed health education teacher education. Physical Education and Sport Pedagogy, v. 23, n. 5 , p. 510-523, 2018.

SIBBETT, Lisa. Toward a transformative criticality for democratic citizenship education.

Democracy \& Education, v. 24, n. 4, p. 1-11, 2016.

STANDING, Guy. The precariat: the new dangerous class. London: Bloomsbury Academic, 2016.

TINNING, Richard. Toward a "modest pedagogy": Reflections on the problematics of critical Pedagogy. Quest, v. 54, n. 3, p. 224-240, 2002.

VERTINSKY, Patricia. Reclaiming space, revisioning the body: the quest for gender-sensitive physical education. Quest, v. 44, n. 3, p. 373-396, 1992.

WALSETH, Kristin; ENGEBRETSEN, Berit; ELVEBAKK, Lisbeth. Meaningful experiences in PE for all students: an activist research approach. Physical Education and Sport Pedagogy, v. 23, n. 3, p. 235-249, 2018. 